\author{
M.T. Jenaliyev ${ }^{1}$, M.M. Amangaliyeva ${ }^{1}$, K.B. Imanberdiyev ${ }^{2}$ \\ ${ }^{1}$ Institute of Mathematics and Mathematical Modeling CS MES RK, Almaty, Kazakhstan; \\ ${ }^{2}$ Al-Farabi Kazakh National University, Almaty, Kazakhstan \\ (E-mail: muvasharkhan@gmail.com)
}

\title{
On the ill-posed problem for the Poisson equation
}

\begin{abstract}
A boundary value problem in a two-dimensional rectangular region for the Poisson equation is studied in the paper. The original ill-posed boundary value problem is transformed to the optimal control problem. The paper gives a brief overview of the problem under study, defines the formulation of the original boundary value problem and optimization problems, proves the existence of a solution to the regularized optimization problem, determines the formulation of the adjoint boundary value problem, studies the optimality conditions, and presents the application of the variable separation method. The necessary and sufficient conditions of optimality in terms of the conjugate boundary value problem are established in the paper, and a strong criterion for the solvability of the ill-posed boundary value problem is obtained. Boundary value problems for the Poisson equation arise in many sections of physics, mechanics, and other applied sciences. So, the stress function in the torsion problem of elastic rods is the solution of the Dirichlet problem, and the height of the liquid rise in the cylindrical capillary is the solution of the Neumann problem. But in many cases practitioners are interested in ill-posed problems for the Poisson equation and their solvability, which determines the relevance of the problem studied in the article.
\end{abstract}

Keywords: Poisson equation, ill-posed problem, optimal control, variational inequality, two-dimensional rectangular area.

Introduction. Recently among the experts on equations of mathematical physics interest in problems that are ill-posed by J. Hadamard has significantly increased [1]. Due to the ill-posed problems classic work by J. Hadamard [1], A.N. Tikhonov [2], M.M. Lavrent'ev [3] and many others can be noted, which have drawn the attention of researchers for ill-posed problems and have made a significant contribution to the development of this important area of mathematics. In this paper we study the ill-posed problem [1]-[8] for the Poisson equation in two-dimensional rectangular domain. The correctness criterion of homogeneous mixed Cauchy problem for the Poisson equation in a rectangular domain was established in the paper of T.Sh. Kalmenov, U.A. Iskakova [6]. In paper [8] the ill-posed problem for the heat equation is considered. The general regularization method for constructing an approximate solution of ill-posed problems of mathematical physics was proposed by A.N. Tikhonov [2]. In the book R. Lattes, J.-L. Lions [4] for regularization of ill-posed boundary value problems the quasiinversion method is proposed. Features and questions of the regularization of Cauchy problems for abstract differential equations with the operator coefficients are studied by I.V. Mel'nikova and U.A. Anufrieva [8].

Statement of the problem. We consider the boundary value problem

$$
\begin{gathered}
y_{t t}(x, t)+y_{x x}(x, t)=f(x, t) ; \\
y(0, t)=0, \quad y(\pi, t)=0 ; \\
y(x,-1)=\varphi_{1}(x), y_{t}(x,-1)=\varphi_{2}(x),
\end{gathered}
$$

in the domain $\Omega=\{x, t \mid 0<x<\pi,-1<t<1\}$ with the additional condition

$$
y_{t}(x, 1) \in \mathcal{U}_{g}, \text { where } \mathcal{U}_{g} \text { is a closed convex set of } L_{2}(0, \pi) .
$$

It is assumed that the data in the problem (1)-(3) satisfies the following conditions:

$$
f \in L_{2}(\Omega), \varphi_{1} \in H_{0}^{1}(0, \pi), \varphi_{2} \in L_{2}(0, \pi) .
$$

In the book R.Lattes, J.-L.Lions [4], it is indicated that problem (1)-(3) is ill-posed in the space $L_{2}(\Omega)$.

In this paper for solving the ill-posed problem we apply methods of optimal control. 
The optimization problem. For the investigation of the problem (1)-(4), we formulate according to it the following optimization problem:

$$
\begin{gathered}
y_{t t}(x, t)+y_{x x}(x, t)=f(x, t) \\
y(0, t)=y(\pi, t)=0 \\
y_{t}(x,-1)=\varphi_{2}(x), y_{t}(x, 1)=\psi(x),
\end{gathered}
$$

with functional of optimality:

$$
\mathcal{J}(\psi)=\int_{0}^{\pi}\left|y_{x}(x,-1)-\varphi_{1}^{\prime}(x)\right|^{2} d x \rightarrow \min _{\psi \in \mathcal{U}_{g}} .
$$

We note, in optimization problem (6)-(9) the function $\psi(x)$ plays the role of control function. In addition, further in the work it will be shown that boundary problem (6)-(8) is well-posed, namely it is uniquely solvable for any given functions $\psi \in \mathcal{U}_{g} \subset L_{2}(0, \pi), f \in L_{2}(\Omega)$.

As it is known from the theory of optimal control optimization problem (6)-(9) is also ill-posed. The illposedness of this problem is shown in the following: functional to be minimized (9) is not strictly convex. Therefore, to small change of the value of the minimized functional (9) the significant change of the control function $\psi(x)$ can correspond in the admissible set $\mathcal{U}_{g}$, or to single value of functional (9) the set of admissible controls can correspond. For such optimization problems, there is an effective regularization method of Tikhonov [2]. To study our problem, we will use stabilizer of Tikhonov [2].

Regularized optimization problem. Effective tool is the method of regularization. In our case

$$
\alpha \int_{0}^{\pi}|\psi(x)|^{2} d x \quad(\alpha>0)
$$

will serve as a stabilizer.

We consider the problem of minimizing the following functional

$$
\mathcal{J}_{\alpha}(y, \psi)=\int_{0}^{\pi}\left|y_{x}(x,-1)-\varphi_{1}^{\prime}(x)\right|^{2} d x+\alpha \int_{0}^{\pi}|\psi(x)|^{2} d x \rightarrow \min _{\psi \in \mathcal{U}_{g}} .
$$

Thus, we have the regularized optimization problem (6)-(8), (10). Due to the presence of the stabilizer the problem has become strictly convex, namely we get well-posed optimization problem. Therefore, for each value $\alpha>0$ this problem has the unique optimal solution that delivers the minimum value to minimized functional (10). However, it does not exclude the fact that the minimum value problem of functional (10) can be strictly greater than zero.

For optimal control problem (6)-(8), (10) we will establish optimality conditions. We introduce the concept of optimal control.

Definition 1. An element $\bar{\psi} \in L_{2}(0, \pi)$ which satisfies the condition

$$
\mathcal{J}_{\alpha}(\bar{\psi})=\inf _{\psi \in \mathcal{U}_{g}} \mathcal{J}_{\alpha}(\psi)
$$

is called the optimal control.

We denote the solution of problem $(6)-(8)$ by $y(x, t ; \psi)$ corresponding to the given control $\psi(x) \in \mathcal{U}_{g}$.

So $y(x, t ; 0)$ corresponds to the solution of problem $(6)-(8)$ when $\psi(x) \equiv 0$. Then, we get

$$
\begin{gathered}
\pi\left(\psi_{1}, \psi_{2}\right)=\int_{0}^{\pi}\left[y_{x}\left(x,-1 ; \psi_{1}\right)-y_{x}(x,-1 ; 0)\right] \times \\
\times\left[y_{x}\left(x,-1 ; \psi_{2}\right)-y_{x}(x,-1 ; 0)\right] d x+\alpha \cdot \int_{0}^{\pi} \psi_{1}(x) \cdot \psi_{2}(x) d x \\
L\left(\psi_{1}\right)=\int_{0}^{\pi}\left[\varphi_{1}^{\prime}(x)-y_{x}(x,-1 ; 0)\right]\left[y_{x}\left(x,-1 ; \psi_{1}\right)-y_{x}(x,-1 ; 0)\right] d x .
\end{gathered}
$$


Here, $\pi\left(\psi_{1}, \psi_{2}\right)$ is the bilinear functional on $\mathcal{U}_{g}, L\left(\psi_{1}\right)$ is the continuous linear functional on admissible set of controls $\mathcal{U}_{g}$, as it will be shown below, that the solution $y(x, t ; \psi)$ of problem (6)-(8) is not only continuous but it is continuously differentiable on control $\psi$. Using the notation, functional (10) can be rewritten as

$$
\mathcal{J}_{\alpha}(\psi)=\pi(\psi, \psi)-2 L(\psi)+\int_{0}^{\pi}\left|y_{x}(x,-1 ; 0)-\varphi_{1}^{\prime}(x)\right|^{2} d x .
$$

The existence of solution of the regularized problem and the variational inequality. The following theorem holds [9].

Theorem 1. As $\pi(\psi, \psi)$ is the continuous symmetric quadratic functional on a $\mathcal{U}_{g}$ and satisfies the condition

$$
\pi(\psi, \psi) \geq c\|\psi\|^{2},(c=\text { const }>0),
$$

then for problem (6)-(8), (10) exists only $\bar{\psi} \in \mathcal{U}_{g}$ :

$$
\mathcal{J}_{\alpha}(\bar{\psi})=\inf _{\psi \in \mathcal{U}_{g}} \mathcal{J}_{\alpha}(\psi)
$$

The inequality (11) holds, as

$$
\pi(\psi, \psi)=\int_{0}^{\pi}\left|y_{x}(x,-1 ; \psi)-y_{x}(x,-1 ; 0)\right|^{2} d x+\alpha \cdot \int_{0}^{\pi} \psi^{2}(x) d x .
$$

The solution of optimization problem (6)-(8), (10) we denote by

$$
\bar{\psi}(x)=\arg \min _{\psi \in \mathcal{U}_{g}} \mathcal{J}_{\alpha}(\psi) .
$$

Further, according to the theory of strictly convex optimization problems the following optimality criterion formulated in terms of the directional derivative is valid.

Proposition 1 (Variational inequality). The function $\bar{\psi} \in \mathcal{U}_{g}$ is a function of the optimal control if and only if the following inequality holds:

$$
\left\langle\mathcal{J}_{\alpha \psi}(\bar{\psi}), \psi-\bar{\psi}\right\rangle \geq 0, \forall \psi \in \mathcal{U}_{g}
$$

namely we have

$$
\begin{gathered}
\int_{0}^{\pi}\left[y_{x}(x,-1 ; \bar{\psi})-\varphi_{1}^{\prime}(x)\right] \cdot \frac{\partial}{\partial x}\left\{y_{\psi}(x,-1 ; \bar{\psi}) \cdot[\psi(x)-\bar{\psi}(x)]\right\} d x+ \\
+\alpha \cdot \int_{0}^{\pi} \bar{\psi}(x) \cdot[\psi(x)-\bar{\psi}(x)] d x \geq 0, \quad \forall \psi \in \mathcal{U}_{g} .
\end{gathered}
$$

We now carry out the necessary further transformations of variational inequality (12). For this purpose, we rewrite the boundary value problem (6)-(8) in the operator form $\mathcal{A} y=\mathcal{F}=\left\{f, \varphi_{2}, \psi\right\}$. As for any admissible controls boundary value problem (6)-(8) is uniquely solvable, then its solution $y(x, t ; \psi)$ can be written in the following form $y(x, t ; \psi)=\mathcal{A}^{-1} \mathcal{F}=\mathcal{A}_{0}^{-1} f+\mathcal{A}_{1}^{-1} \varphi_{2}+\mathcal{A}_{2}^{-1} \psi$.

Next, we take the derivative of this solution in the direction of $\psi-\bar{\psi}$. We have

$$
\begin{gathered}
y_{\psi}(x, t ; \bar{\psi}) \cdot[\psi-\bar{\psi}]=\mathcal{A}^{-1}(\psi-\bar{\psi})= \\
=\mathcal{A}_{0}^{-1} f+\mathcal{A}_{1}^{-1} \varphi_{2}+\mathcal{A}_{2}^{-1} \psi-\left[\mathcal{A}_{0}^{-1} f+\mathcal{A}_{1}^{-1} \varphi_{2}+\mathcal{A}_{2}^{-1} \bar{\psi}\right]=y(x, t ; \psi)-y(x, t ; \bar{\psi})
\end{gathered}
$$

or

$$
y_{\psi}(x, t ; \bar{\psi}) \cdot[\psi-\bar{\psi}]=y(x, t ; \psi)-y(x, t ; \bar{\psi}) .
$$

Thus inequality (12) has the form:

$$
\int_{0}^{\pi}\left[y_{x}(x,-1 ; \bar{\psi})-\varphi_{1}^{\prime}(x)\right] \cdot\left[y_{x}(x,-1 ; \psi)-y_{x}(x,-1 ; \bar{\psi})\right] d x+
$$




$$
+\alpha \cdot \int_{0}^{\pi} \bar{\psi}(x) \cdot[\psi(x)-\bar{\psi}(x)] d x \geq 0, \quad \forall \psi \in \mathcal{U}_{g}
$$

The adjoint boundary value problem. For further study of regularized optimization problem (6)-(8), (10), we introduce the adjoint boundary value problem

$$
\left\{\begin{array}{l}
v_{t t}(x, t)+v_{x x}(x, t)=0, \quad x \in(0, \pi), \quad t \in(-1,1) \\
v(0, t)=v(\pi, t)=0, \quad t \in(-1,1) \\
\int_{\eta}^{x} v_{t}(\xi,-1) d \xi=-y_{x}(x,-1 ; \bar{\psi})+ \\
+\varphi_{1}^{\prime}(x)+y_{\eta}(\eta,-1 ; \bar{\psi})-\varphi_{1}^{\prime}(\eta), \forall 0<\eta<x<\pi \\
v_{t}(x, 1)=0
\end{array}\right.
$$

For its formal conclusion we consider the following expression

$$
\int_{-1}^{1} \int_{0}^{\pi}\left[\tilde{y}_{t t}(x, t)+\tilde{y}_{x x}(x, t)\right] \cdot v(x, t ; \bar{\psi}) d x d t=0
$$

where $\tilde{y}(x, t)=y(x, t ; \psi)-y(x, t ; \bar{\psi})$.

We transform this expression, considering adjoint boundary value problem (14)

$$
\begin{gathered}
\int_{-1}^{1} \int_{0}^{\pi}\left[\tilde{y}_{t t}(x, t)+\tilde{y}_{x x}(x, t)\right] \cdot v(x, t ; \bar{\psi}) d x d t=\int_{0}^{\pi}[\psi(x)-\bar{\psi}(x)] v(x, 1 ; \bar{\psi}) d x+ \\
+\int_{0}^{\pi}[y(x,-1 ; \psi)-y(x,-1 ; \bar{\psi})] \cdot v_{t}(x,-1 ; \bar{\psi}) d x=0 .
\end{gathered}
$$

Thus, we obtain desired adjoint boundary problem (14).

Optimality conditions. By applying the equality

$$
\int_{\eta}^{x} v_{t}(\xi,-1) d \xi=-y_{x}(x,-1 ; \bar{\psi})+\varphi_{1}^{\prime}(x)+y_{\eta}(\eta,-1 ; \bar{\psi})-\varphi_{1}^{\prime}(\eta), \forall 0<\eta<x<\pi,
$$

we rewrite expression (15) as follow

$$
\int_{0}^{\pi}\left[y_{x}(x,-1 ; \bar{\psi})-\varphi_{1}^{\prime}(x)\right] \cdot\left[y_{x}(x,-1 ; \psi)-y_{x}(x,-1 ; \bar{\psi})\right] d x=-\int_{0}^{\pi} v(x, 1) \cdot[\psi(x)-\bar{\psi}(x)] d x,
$$

then from relation (13), we finally obtain the desired variational inequality

$$
\int_{0}^{\pi}[-v(x, 1 ; \bar{\psi})+\alpha \cdot \bar{\psi}(x)] \cdot[\psi(x)-\bar{\psi}(x)] d x \geq 0, \forall \psi \in \mathcal{U}_{g} .
$$

Thus, on the basis of Proposition 1 we have established the optimality conditions, which can be formulated as the following proposition:

Proposition 2. The element $\bar{\psi}(x)$ is the optimal solution to the problem (6)-(8), (10), if and only if it satisfies boundary value problems (6)-(8), (14), and variational inequality (16).

Application of the method of separation of variables. For resolving the conditions of an optimality (6)-(8), (14) and (16) we use a method of separation of variables. We will search solutions of boundary value problems (6)-(8) and (14) in the form

$$
y(x, t)=\sum_{k=1}^{\infty} y_{k}(t) X_{k}(x), \quad v(x, t)=\sum_{k=1}^{\infty} v_{k}(t) X_{k}(x),
$$


where

$$
X_{k}(x)=\frac{\sin k x}{\sqrt{\pi / 2}}, \quad \lambda_{k}=k^{2}, \quad k=1,2, \ldots,
$$

are systems orthonormalized eigenfunctions and eigenvalues for a spectral problem:

$$
X^{\prime \prime}(x)=\lambda \cdot X(x), \quad X(0)=X(\pi)=0 .
$$

From (6)-(8), (14) and (16) we accordingly obtain

$$
\begin{gathered}
\left\{\begin{array}{l}
y_{k}^{\prime \prime}(t)-k^{2} y_{k}(t)=f_{k}(t), t \in(-1,1) ; \\
y_{k}^{\prime}(-1)=\varphi_{2 k} ; y_{k}^{\prime}(1)=\bar{\psi}_{k} ; k=1,2, \ldots ;
\end{array}\right. \\
\left\{\begin{array}{c}
v_{k}^{\prime \prime}(t)-k^{2} v_{k}(t)=0, t \in(-1,1) ; \\
v_{k}^{\prime}(-1)=k^{2}\left[y_{k}(-1)-\varphi_{1 k}\right] ; v_{k}^{\prime}(1)=0 ; k=1,2, \ldots ;
\end{array}\right. \\
{\left[-v_{k}(1)+\alpha \cdot \bar{\psi}_{k}\right] \cdot\left[\psi_{k}-\bar{\psi}_{k}\right] \geq 0, \text { for } \forall \psi_{k}, k=1,2, \ldots,}
\end{gathered}
$$

where $f_{k}(t), \varphi_{1 k}, \varphi_{2 k}, \bar{\psi}_{k}, \psi_{k}, k=1,2, \ldots$ are Fourier-coefficients of functions $f(x, t), \varphi_{1}(x), \varphi_{2}(x)$ and $\bar{\psi}(x)$, $\psi(x)$ on system (17).

Assume us write solutions of boundary value problems (18) and (19):

$$
\begin{gathered}
y_{k}(t)=\bar{\psi}_{k} \cdot \frac{\cosh k(t+1)}{\sinh 2 k}-\varphi_{2 k} \cdot \frac{\cosh k(1-t)}{k \sinh 2 k}+\int_{-1}^{1} G_{k}(t, \tau) \cdot f_{k}(\tau) d \tau \\
v_{k}(t)=-\left[y_{k}(-1)-\varphi_{1 k}\right] \cdot \frac{k \cosh k(1-t)}{\sinh 2 k}
\end{gathered}
$$

where

$$
G_{k}(t, \tau)=\left\{\begin{array}{l}
-\frac{\cosh k(1-t) \cdot \cosh k(1+\tau)}{\sinh 2 k},-1<\tau<t<1 \\
-\frac{\cosh k(1-\tau) \cdot \cosh k(1+t)}{\sinh 2 k},-1<t<\tau<1 .
\end{array}\right.
$$

From (21)-(22) and (20) we find

$$
\begin{gathered}
-v_{k}(1)=\left[y_{k}(-1)-\varphi_{1 k}\right] \cdot \frac{k}{\sinh 2 k}, \\
y_{k}\left(-1 ; \bar{\psi}_{k}\right)=-\varphi_{2 k} \frac{\operatorname{coth} 2 k}{k}+\bar{\psi}_{k} \frac{1}{\sinh 2 k}+\int_{-1}^{1} G_{k}(-1, \tau) f_{k}(\tau) d \tau, \\
{\left[A_{k \alpha} \bar{\psi}_{k}-\varphi_{1 k}-\varphi_{2 k} \frac{\operatorname{coth} 2 k}{k}+\int_{-1}^{1} G_{k}(-1, \tau) f_{k}(\tau) d \tau\right] \cdot\left[\psi_{k}-\bar{\psi}_{k}\right] \geq 0 \text { for all } \psi_{k},}
\end{gathered}
$$

where $A_{k \alpha}=\frac{k+\alpha \sinh ^{2} 2 k}{k \sinh 2 k}, k=1,2, \ldots$

Now we put, that $\mathcal{U}_{g} \equiv L_{2}(0, \pi)$. Since the functions $\psi(x)$ do not have any restrictions except for belonging to the space $L_{2}(0, \pi)$, from $(23)$ we can find the optimal values of Fourier coefficients $\bar{\psi}_{k}, k=1,2, \ldots$ :

$$
\bar{\psi}_{k}=A_{k \alpha}^{-1}\left[\varphi_{1 k}+\varphi_{2 k} \frac{\operatorname{coth} 2 k}{k}-\int_{-1}^{1} G_{k}(-1, \tau) f_{k}(\tau) d \tau\right] .
$$

Further, as $\alpha \rightarrow 0(21)$ and (24) imply that

$$
y_{k 0}(t)=\lim _{\alpha \rightarrow 0} y_{k}(t)=\varphi_{1 k} \cosh k(1+t)+\varphi_{2 k} \frac{\sinh k(1+t)}{k}-
$$




$$
\begin{gathered}
-\cosh k(1+t) \int_{-1}^{1} G_{k}(-1, \tau) f_{k}(\tau) d \tau+\int_{-1}^{1} G_{k}(t, \tau) \cdot f_{k}(\tau) d \tau ; \\
\bar{\psi}_{k 0}=\lim _{\alpha \rightarrow 0} \bar{\psi}_{k}=\varphi_{1 k} \sinh 2 k+\varphi_{2 k} \frac{\cosh 2 k}{k}-\sinh 2 k \int_{-1}^{1} G_{k}(-1, \tau) f_{k}(\tau) d \tau .
\end{gathered}
$$

Additionally, the solutions $y_{k}(t)$ found under formula (21) according to optimal Fourier coefficients $\bar{\psi}_{k}, k=1,2, \ldots(24)$ must satisfy to limiting relations: $\lim _{\alpha \rightarrow 0} y_{k}(-1)=\varphi_{1 k}$, which really hold. And it is coordinated with a condition $y(x,-1)=\varphi_{1}(x)$ from $(3)$.

Thus, for a finding of the exact solution of problem (6)-(8) according to (26) we construct the following series:

$$
\bar{\psi}(x)=\sum_{k=1}^{\infty} \sqrt{2 / \pi} \sinh 2 k\left[\varphi_{1 k}+\varphi_{2 k} \frac{\operatorname{coth} 2 k}{k}-\int_{-1}^{1} G_{k}(-1, \tau) f_{k}(\tau) d \tau\right] \sin k x
$$

and for initial Cauchy-Dirichlet problem (1)-(3) we obtain the solution on the basis of formulas (25).

Conclusion. From equalities (25) and (26) the following directly holds:

Firstly, with growth of index $k$ and at $\alpha \rightarrow 0$ the Fourier-coefficients of the function $\bar{\psi}(x)$ and, respectively, the solution $y_{k}(t)$ can increase without limit if this growth is not be «suppressed» with corresponding more rapid decrease of the absolute values of the coefficients $\varphi_{1 k}, \varphi_{2 k}$ and values of norms $\left\|f_{k}(t)\right\|_{L_{2}(-1,1)}$.

Secondly, boundary problem (1)-(3) under conditions (5) has unique $L_{2}$-strong solution [10] if and only if

$$
\left\{\exp \{2 k\} \cdot \varphi_{1 k}\right\}_{k=1}^{\infty}, \quad\left\{k^{-1} \exp \{2 k\} \cdot \varphi_{2 k}\right\}_{k=1}^{\infty} ; \quad\left\{\exp \{2 k\} \cdot\left\|f_{k}(\tau)\right\|_{L_{2}(-1,1)}\right\}_{k=1}^{\infty} \subset l_{2} .
$$

Thus, it is clear not only the meaning of regularization in problem (6)-(8) and (10), but also the nature of incorrectness in Cauchy-Dirichlet problem (1)-(3) [6, 7]. And regularization allows us to find an approximate solution.

Thirdly, we consider the example of Hadamard [11;37]. To receive analogue of the Hadamard example in problem (1)-(3) it is necessary to accept:

$$
f(x, t)=0, \varphi_{1}(x)=0, \varphi_{2}(x)=\sqrt{2 / \pi} \cdot k \cdot \exp \{-\sqrt{k}\} \sin k x, k \in \mathbf{N} .
$$

Really, the solution of Cauchy-Dirichlet problem for Laplace equation has the form:

$$
y(x, t)=\sqrt{2 / \pi} \cdot \exp \{-\sqrt{k}\} \sin k x \cdot \sinh k(t+1), k \in \mathbf{N} .
$$

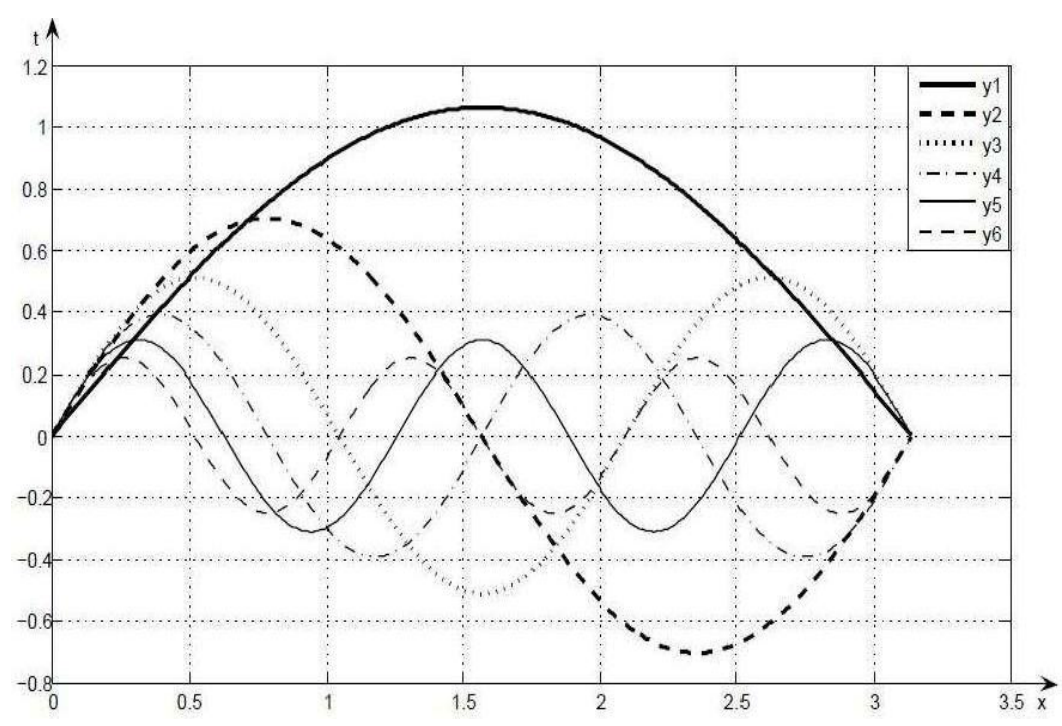

Figure. Graph of solution $y_{k}(x, t)$ at $k=\overline{1,6}$ of $(28)$ 
In Figure are shows the graphs of the solution $y k(x, t)$ at $k=1,6$ of (28). This solution of a problem in example of Hadamard considered by us is unique. Moreover, as $k \rightarrow \infty$ the function $\varphi_{2}(x)$ approaches uniformly zero and that not only, but also all its derivatives approache zero and it belongs to space $L_{2}(0, \pi)$. However the solution (28) at any $t>-1$ has the form of a sinusoid with an arbitrarily large amplitude and does not belong to space $L_{2}((0, \pi) \times(-1,1))$.

In order to the function $\varphi_{2}(x)$ satisfied to condition (27), it is necessary and sufficient, that the Fouriercoefficients $\varphi_{2 k}$ had the asymptotic behavior for large $k$ of order $\exp \{-(2+\varepsilon) k\}$ where $\varepsilon>0$. In example of Hadamard considered by us we have asymptotic which is only equal to $\exp \{-\sqrt{k}\}$, and it is obviously not enough for a correctness of Cauchy-Dirichlet problem for Poisson equation.

\title{
References
}

1 Адамар Ж. Задача Коши для линейных уравнений с частными производными гиперболического типа / Ж.Адамар. - М.: Наука, 1978. - 352 с.

2 Тихонов А.Н. Методы решения некорректных задач / А.Н. Тихонов, В.Я. Арсенин. - М.: Наука, 1979. - $142 \mathrm{c}$.

3 Лаврентьев М.М. Задача Коши для уравнения Лапласа / М.М. Лаврентьев // Известия АН СССР. Сер. математическая. - 1956. - Т. 20. - № 6. - С. 819-842.

4 Lattes R. Methode de quasireversibilite et applications / R.Lattes, J.-L. Lions. - Paris: Dunod, 1967. $336 \mathrm{p}$.

5 Кабанихин С.И. Обратные и некорректные задачи / С.И. Кабанихин. - Новосибирск: Сибир. науч. изд-во, 2009. - 457 с.

6 Кальменов Т.Ш. Критерий сильной разрешимости смешанной задачи Коши для уравнения Лапласа / Т.Ш. Кальменов, У.А. Искакова // Докл. РАН. - 2007. - Т. 414. - № 2. - С. 168-171.

7 Дженалиев М.Т. Материалы совещания Российско-Казахстанской рабочей группы по вычислительным и информационным технологиям / М.Т.Дженалиев, Т.Ш. Кальменов, М.И. Рамазанов. (Алматы, 16-18 марта 2009). - Алматы: КазНУ им.аль-Фараби, 2009. - С. 162-167.

8 Melnikova I.V. Journal of Mathematical Sciences / I.V. Melnikova, U.A. Anufrieva. - 2008. - Vol. 148. - No. 4. - P. 481-632.

9 Лионс Ж.-Л. Оптимальное управление системами, описываемыми уравнениями с частными производными / Ж.-Л. Лионс. - М.: Мир, 1972. - 414 с.

10 Дезин А.А. Общие вопросы теории граничных задач / А.А. Дезин. - М.: Наука, 1980. - 207 с.

11 Соболев С.Л. Уравнения математической физики / С.Л. Соболев. - М.: Наука, 1966. - 444 с.

\section{М.Т. Жиенәлиев, М.М. Аманғалиева, Қ.Б. Иманбердиев \\ Пуассон теңдеуі үшін корректі емес есеп туралы}

\begin{abstract}
Мақалада Пуассон теңдеуі үшін екіөлшемді тікбұрышты облыста шекаралық есеп қарастырылды. Корректі емес шеттік есеп тиімді басқару есебіне келтірілді. Авторлар зерттелетін мәселеге қысқаша шолу жасап, бастапқы шеттік есеп пен тиімділік есептерінің қойылымын анықтап, регуляризацияланған тиімділік есебінің шешімінің бар болуын дәлелдей отырып, түйіндес шеттік есептің қойылымын анықтап, тиімділік шарттарын зерттеген, сондай-ақ айнымалыларды бөліктеу әдісінің қолданылуы келтірілген. Жұмыста тиімділіктің қажетті және жеткілікті шарттары түйіндес шеттік есеп терминдерінде табылып, корректі емес шеттік есептің шешімділігінің әлді критерийі алынған. Пуассон теңдеуі үшін шеттік есептер физиканың, механика және де басқа қолданбалы ғылымдардың көптеген салаларында кездеседі. Серпімді өзектің бұралуы туралы есебіндегі кернеу функциясы Дирихле есебінің шешімі, ал цилиндрлік капиллярдағы сұйықтың көтерілуінің биіктігі Нейман есебінің шешімі болып табылады. Дегенмен көптеген жағдайда практиктерді Пуассон теңдеуі үшін корректі емес есептер және олардың шешімділігі мәселелері қызықтырады, сондықтан мақаладағы зерттелген мәселенің өзектілігі артады.
\end{abstract}

Kiлm сөздер: Пуассон теңдеуі, корректі емес есеп, түйіндес шекаралық есеп, тиімді басқару, тиімділік шарттары, регуляризация, вариациялық теңсіздік, екіөлшемді тікбұрышты облыс. 


\section{М.Т. Дженалиев, М.М. Амангалиева, К.Б. Иманбердиев \\ О некорректной задаче для уравнения Пуассона}

В работе рассмотрена краевая задача в двумерной прямоугольной области для уравнения Пуассона. Изученная некорректная краевая задача сводится к задаче оптимального управления. Авторами дан краткий обзор исследуемой проблемы, определены постановка исходной краевой задачи и задачи оптимизации, доказано существование решения регуляризированной задачи оптимизации, определена постановка сопряженной краевой задачи, исследованы условия оптимальности, представлено применение метода разделения переменных. В работе установлены необходимые и достаточные условия оптимальности в терминах сопряженной краевой задачи, а также получен сильный критерий разрешимости некорректной краевой задачи. Краевые задачи для уравнения Пуассона возникают во многих разделах физики, механики и других прикладных наук. Так, функция напряжений в задаче о кручении упругих стержней является решением задачи Дирихле, а высота подъёма жидкости в цилиндрическом капилляре - решением задачи Неймана. Во многих случаях практиков интересуют некорректные задачи для уравнения Пуассона и вопросы их разрешимости, что определяет актуальность исследуемой в статье проблемы.

Ключевые слова: уравнение Пуассона, некорректная задача, сопряженная граничная задача, оптимальное управление, условия оптимальности, регуляризация, вариационное неравенство, двумерная прямоугольная область.

\section{References}

1 Hadamard, J. (1978). Zadacha Koshi dlia lineinykh uravnenii s chastnymi proizvodnymi hiperbolicheskoho tipa [The Cauchy problem for linear partial differential equations of hyperbolic type]. Moscow: Nauka [in Russian].

2 Tikhonov, A.N., \& Arsenin, V.Ya. (1979). Metody resheniia nekorrektnykh zadach /Methods for solving ill-posed problems]. Moscow: Nauka [in Russian].

3 Lavrent'ev, M.M. (1956). Zadacha Koshi dlia uravneniia Laplasa [The Cauchy problem for the Laplace equation]. Izvestiia AN SSSR. Seriia matematicheskaia - Reports of the Academy of Sciences. Series mathematics, Vol. 20, 6, 819-842 [in Russian].

4 Lattes, R. \& Lions, J.-L. (1967). Methode de quasireversibilite et applications. Paris: Dunod.

5 Kabanikhin, S.I. (2009). Obratnye i nekorrektnye zadachi [Inverse and ill-posed problems]. Novosibirsk: Sibirskoe nauchnoe izdatelstvo [in Russian].

6 Kalmenov, T.Sh., \& Iskakova, U.A. (2007). Kriterii silnoi razreshimosti smeshannoi zadachi Koshi dlia uravneniia Laplasa [Criterion for strong solvability of a mixed Cauchy problem for the Laplace equation]. Doklady RAN, Vol. 414, 2, 168-171 [in Russian].

7 Jenaliyev, M.T., Kalmenov, T.Sh., \& Ramazanov, M.I. (2009). Materialy soveshchaniia Rossiisko-Kazakhstanskoi rabochei hruppy po vychislitelnym i informatsionnym tekhnolohiiam [Selected materials of the conference Meeting Russian-Kazakh working group on computing and information technology]. (pp. 162167). Almaty: KazNU [in Russian].

8 Mel'nikova, I.V., \& Anufrieva, U.A. (2008). Journal of Mathematical Sciences, Vol. 148, 4, 481-632.

9 Lions, J.-L. (1972). Optimalnoe upravlenie systemami, opisyvaemymi uravneniiami s chastnymi proizvodnymi [Optimal control of systems described by partial differential equations]. Moscow: Mir [in Russian].

10 Dezin, A.A. (1980). Obshchie voprosy teorii hranichnykh zadach /General questions of the theory of boundary value problems]. Moscow: Nauka [in Russian].

11 Sobolev, S.L. (1966). Uravneniia matematicheskoi fiziki [Mathematical Physics Equations]. Moscow: Nauka [in Russian]. 